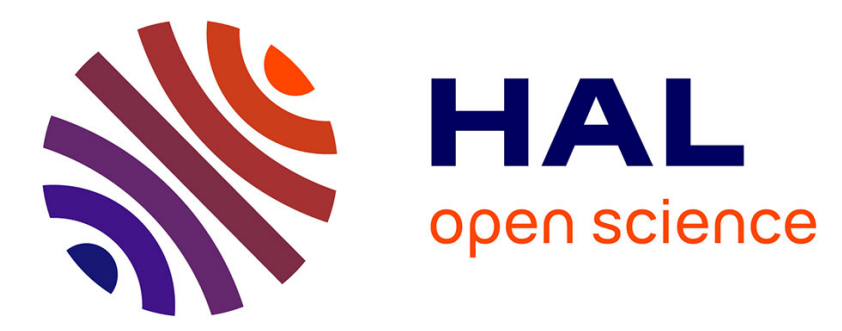

\title{
Barium siloxides and catalysed formation of Si-O-Si' motifs
}

Erwann Le Coz, Samia Kahlal, Jean-Yves Saillard, Thierry Roisnel, Vincent Dorcet, Jean-François Carpentier, Yann Sarazin

\section{- To cite this version:}

Erwann Le Coz, Samia Kahlal, Jean-Yves Saillard, Thierry Roisnel, Vincent Dorcet, et al.. Barium siloxides and catalysed formation of Si-O-Si' motifs. Chemistry - A European Journal, 2019, 25 (59), pp.13509-13513. 10.1002/chem.201903676 . hal-02280837

\section{HAL Id: hal-02280837 https://hal-univ-rennes1.archives-ouvertes.fr/hal-02280837}

Submitted on 19 Nov 2019

HAL is a multi-disciplinary open access archive for the deposit and dissemination of scientific research documents, whether they are published or not. The documents may come from teaching and research institutions in France or abroad, or from public or private research centers.
L'archive ouverte pluridisciplinaire HAL, est destinée au dépôt et à la diffusion de documents scientifiques de niveau recherche, publiés ou non, émanant des établissements d'enseignement et de recherche français ou étrangers, des laboratoires publics ou privés. 
WILEY-VCH

\title{
Barium siloxides and catalysed formation of Si-O-Si' motifs
}

\author{
Erwann Le Coz, Samia Kahlal, Jean-Yves Saillard, ${ }^{*}$ Thierry Roisnel, Vincent Dorcet, Jean-François \\ Carpentier and Yann Sarazin*
}

\begin{abstract}
The first unsupported barium siloxide, the homoleptic dimer $\left[\mathrm{Ba}_{2}\left\{\mu_{2}-\mathrm{OSi}\left(\mathrm{SiMe}_{3}\right)_{3}\right\}_{3}\left\{\mathrm{OSi}\left(\mathrm{SiMe}_{3}\right)_{3}\right\}\right]$, is presented, and its structural features are discussed in the light of DFT computations. This complex together with the related $\left[\mathrm{Ba}\left\{\mu_{2}-\mathrm{OSi}\left(\mathrm{SiMe}_{3}\right)_{3}\right\}\left\{\mathrm{N}\left(\mathrm{SiMe}_{3}\right)_{2}\right\}\right]_{2}$ and their parent $\left[\mathrm{Ba}\left\{\mathrm{N}\left(\mathrm{SiMe}_{3}\right)_{2}\right\}_{2}\right]_{2}$, mediate the formation of asymmetric siloxanes $\mathrm{R}_{3} \mathrm{Si}-\mathrm{O}-\mathrm{SiR}_{3}$ through the first case of main group metalmediated dehydrocoupling of silanols and hydrosilanes. Early kinetic analysis highlights an unusual catalytic manifold.
\end{abstract}

Molecular alkaline-earth $(\mathrm{Ae}=\mathrm{Ca}, \mathrm{Sr}, \mathrm{Ba})$ alkoxides and fluoroalkoxides have been employed as useful precursors for deposition of metal oxide or fluoride thin films..$^{[1,2]}$ More recently, they have also been used as effective ring-opening polymerisation catalysts. ${ }^{[3]}$ Yet, the $\pi$-donating ability of alkoxides combined to the hard, oxophilic nature of Ae metals often leads to the formation of multinuclear or ill-defined alkoxides of limited solubility or volatility. The propensity to produce aggregates increases upon descending group 2, and is particularly pronounced for the very large $(1.35 \AA) \mathrm{Ba}^{2+}$ cation. It generates complexes where bonding is essentially ionic, and where coordination numbers often reach 8 or more. While a number of heterobimetallic barium alkoxides species are also known, ${ }^{[4]}$ homometallic Ba-alkoxides are scarce and form aggregates, e.g. $\left[\mathrm{Ba}_{5}(\mathrm{Omesityl})_{5}(\mathrm{OMe})_{5}(\mathrm{dme})_{4}\right] \cdot \mathrm{dme} .^{[5]}$ Some other derivatives of Ba-alkoxides of low nuclearity have also been reported, e.g. twocoordinate Ba-boryloxides that catalyse the dehydrocoupling of hydrosilanes and borinic acids. ${ }^{[6]}$ Some Ba-siloxides also exist. Yet, they are either stabilised by solvent or macrocyclic donors,

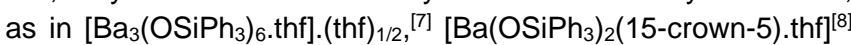
$\left[\mathrm{Ba}_{2}(\mathrm{OSitBu})_{4}\right.$.thf], ${ }^{\left[{ }^{[9]}\right.}$ and $\left.\left[\mathrm{Ba}_{3}\left(\mathrm{OSiPh}_{2} \mathrm{OSiPh} \mathrm{O}_{2} \mathrm{O}\right)_{3} \text { (tetraglyme }\right)_{2}\right],{ }^{[10]}$ or the siloxide is the anionic part of a multidentate ligand. ${ }^{[11-12]}$ To our knowledge, no occurrence of solvent-free, unsupported Basiloxide is known to date.

Metal-mediated dehydrocoupling catalysis, notably for the dehydrogenation of amine-boranes, ${ }^{[13-15]}$ has been attracting sustained interest. Ae complexes provide effective catalysts for these reactions. ${ }^{[16]}$ They also enable the formation of silazanes through $\mathrm{N}-\mathrm{H} / \mathrm{H}-\mathrm{Si}$ heterodehydrocoupling, ${ }^{[17-20]}$ and that of borasiloxanes from $\mathrm{BO}-\mathrm{H} / \mathrm{H}-\mathrm{Si}$ coupling. ${ }^{[6]}$ Yet, metal catalysts, and a fortiori Ae-based ones, have seldom been implemented in the controlled production of siloxanes, despite the commercial importance of oligo- and polysiloxanes. ${ }^{[21-22]}$ Asymmetric $\mathrm{R}_{3} \mathrm{Si}-\mathrm{O}$ -

[a] E. Le Coz, Dr. S. Kahlal, Prof. Dr. J.-Y. Saillard, Dr. T. Roisnel, Dr. V. Dorcet, Prof. Dr. J.-F. Carpentier, Dr. Y. Sarazin Univ Rennes, CNRS, ISCR (Institut des Sciences Chimiques de Rennes) - UMR 6226, F-35000 Rennes (France)

E-mail: jean-yves.saillard@univ-rennes1.fr

E-mail: yann.sarazin@univ-rennes1.fr

Supporting information for this article is given via a link at the end of the document.
$\mathrm{SiR}_{3}$ siloxanes can be prepared by conventional condensations involving a silanol (with a base) or a metal silanolate and a halosilane $\mathrm{R}_{3} \mathrm{SiX}$, but these protocols generate large amounts of waste by-products. ${ }^{[23]}$ Instead, a handful of catalysed processes relying on late transition metals are known. Rhodium(I) compounds ${ }^{[24]}$ and $\left[\mathrm{AuCl}\left(\mathrm{PPh}_{3}\right)\right]^{[25]}$ catalyse the coupling of tertiary silanols with hydrosilanes. $\left[\mathrm{Ru}_{3}(\mathrm{CO})_{12}\right]$ allows the one-pot functionalisation of polyhedral oligomeric silsesquioxanes (POSS) upon coupling of hydrosilanes with POSS-silanols. ${ }^{[26]}$ In addition, the coupling of silanols with alkoxysilanes promoted by $\mathrm{B}\left(\mathrm{C}_{6} \mathrm{~F}_{5}\right)_{3}$ also yields siloxanes ${ }^{[27-28]}$ and can be used to synthesise oligosiloxanes. [29-30]

As part of our programme aimed at implementing Ae metals complexes in molecular catalysis as an alternative to expensive transition metals, we describe here the first examples of unsupported, soluble barium-siloxides. Structural features are examined in the light of DFT computations. The utilisation of these main group metal complexes to catalyse the selective formation of asymmetric siloxanes is discussed, along with preliminary kinetic insight.

The reaction of $\left.\left[\mathrm{Ba}\left\{\mathrm{N}\left(\mathrm{SiMe}_{3}\right)_{2}\right\}_{2} \text {. (thf }\right)_{2}\right]$ with two equivalents of the bulky silanol $\left(\mathrm{Me}_{3} \mathrm{Si}\right)_{3} \mathrm{SiOH}^{[31]}$ afforded the dinuclear thf adduct $\left[\mathrm{Ba}_{2}\left\{\mathrm{OSi}\left(\mathrm{SiMe}_{3}\right)_{3}\right\}_{4}\right.$.thf] (12.thf, Scheme 1). This compound, which only contains one molecule of coordinated thf for two Ba cations, was characterised by NMR spectroscopy. The ${ }^{1} \mathrm{H}$ NMR spectrum recorded in benzene- $d_{6}$ indicates that the thf molecule remains bound to a metal in this solvent $\left(\delta_{1 \mathrm{H}}=3.40\right.$ and $\left.1.30 \mathrm{ppm}\right)$.

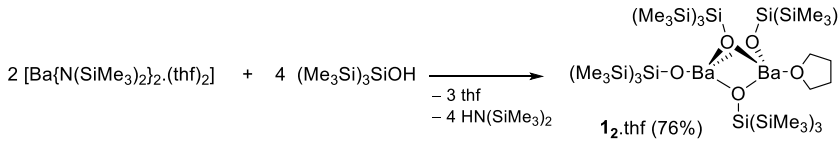

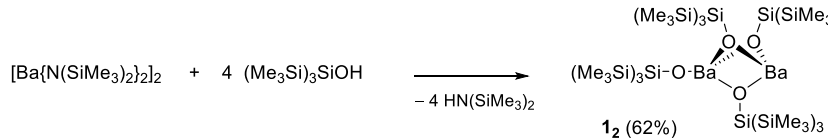

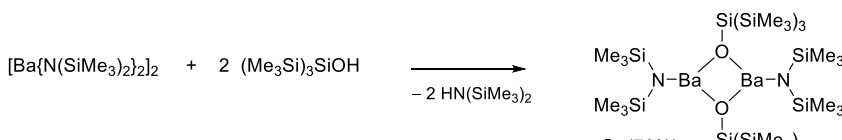

$$
\begin{aligned}
& \mathbf{2}_{\mathbf{2}}(\mathbf{7 6} \%) \quad \mathrm{Si}\left(\mathrm{SiMe}_{3}\right)_{3}
\end{aligned}
$$

(1)

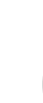

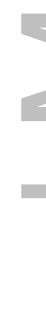

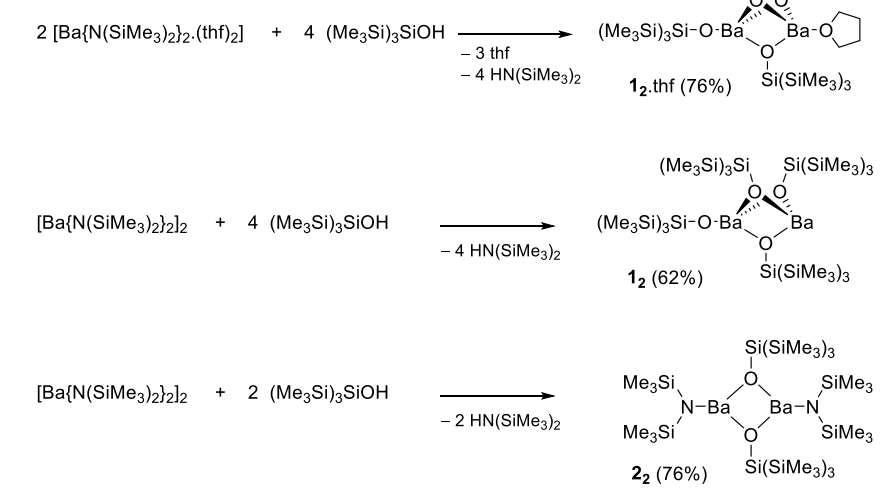

Scheme 1. Synthesis of barium-siloxides (reactions in petroleum ether, $20^{\circ} \mathrm{C}$ ).

Single crystals of $\mathbf{1}_{\mathbf{2}}$.thf were analysed by $\mathrm{X}$-ray diffraction methods. Although the refined XRD structure of the compound is crippled by excessive anisotropy for some methyl groups (see the $\mathrm{SI})$, the connectivity was established without ambiguity. The complex exists as a dimer bridging by three $\mathrm{O}_{\text {siloxide }}$ atoms, with an 
additional terminal siloxide moiety on one barium, and a capping thf molecule on the other one. Both $\mathrm{Ba}$ atoms are four-coordinate. The structure recalls that established for $\left[\mathrm{Ba}_{2}\left(\mathrm{OSitBu}_{3}\right)_{4}\right.$. thf]. ${ }^{\left[{ }^{9]}\right.}$

The targeted solvent-free homoleptic complex, $\left[\mathrm{Ba}_{2}\left\{\mu_{2}-\right.\right.$ $\left.\left.\mathrm{OSi}\left(\mathrm{SiMe}_{3}\right)_{3}\right\}_{3}\left\{\mathrm{OSi}\left(\mathrm{SiMe}_{3}\right)_{3}\right\}\right]\left(\mathbf{1}_{\mathbf{2}}\right)$, was obtained upon reaction of $\left[\mathrm{Ba}\left\{\mathrm{N}\left(\mathrm{SiMe}_{3}\right)_{2}\right\}_{2}\right]_{2}$ with $\left(\mathrm{Me}_{3} \mathrm{Si}\right)_{3} \mathrm{SiOH}$. It was reproducibly isolated as colourless crystals in a non-optimised $60-65 \%$ yield after recrystallisation. In benzene- $d_{6}$, compound $\mathbf{1} 2$ gives rise to single resonances at $\delta_{1 \mathrm{H}}=0.35 \mathrm{ppm}$ and $\delta_{13 \mathrm{C}}=1.76\left({ }^{1} \mathrm{~J}_{\mathrm{Si}-\mathrm{C}}=41 \mathrm{~Hz}\right) \mathrm{ppm}$ in its ${ }^{1} \mathrm{H}$ and ${ }^{13} \mathrm{C}\left\{{ }^{1} \mathrm{H}\right\}$ NMR spectra. The ${ }^{29} \mathrm{Si}\left\{{ }^{1} \mathrm{H}\right\}$ NMR spectrum is characterised by two resonances at $\delta_{29 S i}=-19.37$ (major) and 27.02 (minor) ppm, assigned respectively to $\mathrm{Si}\left(\mathrm{SMe}_{3}\right)_{3}$ and $\mathrm{Si}\left(\mathrm{SiMe}_{3}\right)_{3}$ atoms. ${ }^{[31]}$ The molecular solid-state structure of $\mathbf{1}_{\mathbf{2}}$ is depicted in Figure 1 (one of the four independent but very similar molecules in the asymmetric unit represented). The complex forms a $C_{3}$-symmetric dimer. The overall arrangement resembles that in 12.thf, except for the absence of thf at Ba1. There are hence three bridging siloxides, and a single terminal one, with nonequivalent barium atoms: one (Ba1) is formally three-coordinate, while the other (Ba2) is four-coordinate. Atypically for barium, the geometry about Ba1 is trigonal pyramidal. The interatomic distances and angles around $\mathrm{Ba} 1$ are commensurate with those in $\left[\mathrm{Ba}_{2}(\mathrm{OSitBu})_{4}\right)_{4}$.thf]. ${ }^{[9]}$ Short intra- and intermolecular $\mathrm{Ba} 1-\mathrm{H}$ interatomic distances are present in $\mathbf{1}_{2}$ (Figure 2). This suggests the existence of $\mathrm{Ba} 1 \cdots \mathrm{H}-\mathrm{C}$ agostic interactions and formation of monodimensional coordination polymers, although spectroscopic evidence could not be found to support this picture. These interactions bring steric protection and electronic density to the otherwise accessible $\mathrm{Ba} 1$ metal atom; by comparison, the pertaining coordination site is occupied by a thf molecule in $\mathbf{1}_{\mathbf{2}}$.thf.

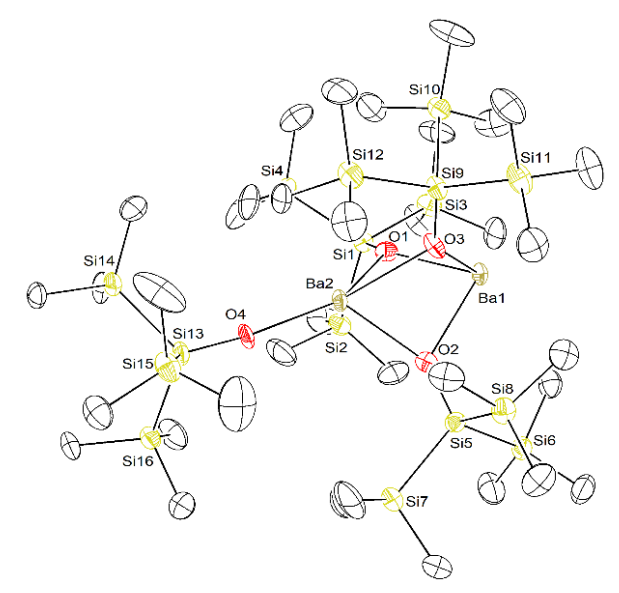

Figure 1. ORTEP view of the molecular solid-state structure of $\left[\mathrm{Ba}_{2}\left\{\mu_{2}\right.\right.$ $\left.\left.\mathrm{OSi}\left(\mathrm{SiMe}_{3}\right)_{3}\right\}_{3}\left\{\mathrm{OSi}\left(\mathrm{SiMe}_{3}\right)_{3}\right\}\right]\left(\mathbf{1}_{2}\right)$. Only one of the four similar molecules in the asymmetric unit is depicted. $\mathrm{H}$ atoms omitted for clarity. Ellipsoids at the $50 \%$ probability level. Representative interatomic distances $(\AA)$ and angles $\left({ }^{\circ}\right)$ : Ba1$\mathrm{O} 3=2.477(8)$, Ba1-O1 $=2.509(8), \mathrm{Ba} 1-\mathrm{O} 2=2.514(7), \mathrm{Ba} 2-\mathrm{O} 4=2.414(7)$, Ba2 $\mathrm{O} 2=2.612(8), \mathrm{Ba} 2-\mathrm{O} 1=2.673(7), \mathrm{Ba} 2-\mathrm{O} 3=2.719(7) ; \mathrm{O} 3-\mathrm{Ba} 1-\mathrm{O} 1=82.00(2)$, O3-Ba1-O2 = 79.00(2), O1-Ba1-O2 = 78.80(2), O4-Ba2-O2 = 125.80(3), O4$\mathrm{Ba} 2-\mathrm{O} 1=138.30(3)$, O2-Ba2-O1 = 74.20(2), O4-Ba2-O3 = 142.10(3), O2-Ba2$\mathrm{O} 3=73.10(2), \mathrm{O} 1-\mathrm{Ba} 2-\mathrm{O} 3=74.70(2), \mathrm{Si} 13-\mathrm{O} 4-\mathrm{Ba} 2=173.50(5)$.

The geometry about Ba2 forms a distorted tetrahedron $\left(\mathrm{T}_{4}=\right.$ 0.56). ${ }^{[32]}$ The Ba2-Obridge distances to bridging O-atoms (2.612(8)-
$2.719(7) \AA$ ) are substantially longer than the Ba1-O bridge ones (2.477(8), 2.509(8) $\AA$ ). The Ba2-O4 bond length to the terminal siloxide (which is nearly linear, Si13-O4-Ba2 $=173.50(5)^{\circ}$ ) of $2.414(7) \AA$ is much shorter.

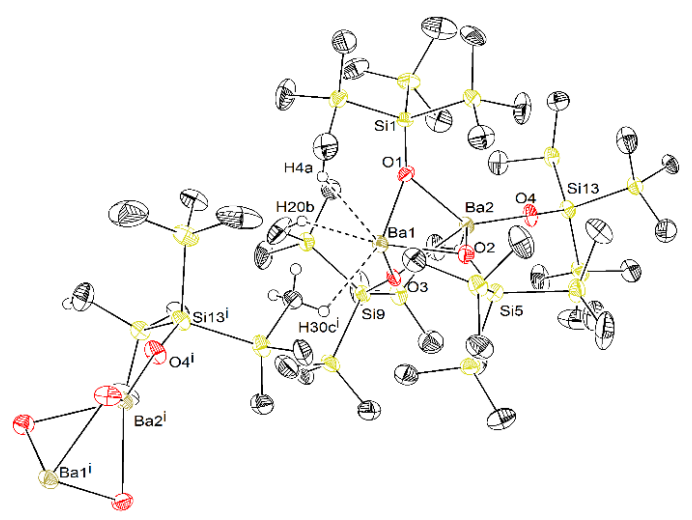

Figure 2. ORTEP representation of the molecular solid-state structure of $\left[\mathrm{Ba} 2\left\{\mu_{2}-\mathrm{OSi}\left(\mathrm{SiMe}_{3}\right)_{3}\right\}_{3}\left\{\mathrm{OSi}\left(\mathrm{SiMe}_{3}\right)_{3}\right\}\right]$ (12), showing intra- and intermolecular $\mathrm{Ba} \cdots \mathrm{H}-\mathrm{C}$ interactions as dashed lines. Non-interacting $\mathrm{H}$ atoms not shown. Interatomic distances $(\AA)$ : $\mathrm{Ba} 1-\mathrm{H} 4 \mathrm{a}=2.7447(6), \mathrm{Ba} 1-\mathrm{H} 20 \mathrm{~b}=2.7859(9)$, Ba1$H 30 \mathrm{C}^{\mathrm{i}}=2.8762(6)$. Symmetry operations: $-x, y+1 / 2,-z$.

$\left[\mathrm{Ba}\left\{\mu_{2}-\mathrm{OSi}\left(\mathrm{SiMe}_{3}\right)_{3}\right\}\left\{\mathrm{N}\left(\mathrm{SiMe}_{3}\right)_{2}\right\}\right]_{2} \quad\left(\mathbf{2}_{2}\right)$, a mixed siloxo/amido complex, ${ }^{[33]}$ was isolated in $76 \%$ yield as colourless single crystals by reacting $\left[\mathrm{Ba}\left\{\mathrm{N}\left(\mathrm{SiMe}_{3}\right)_{2}\right\}_{2}\right]_{2}$ with one equivalent of $\left(\mathrm{Me}_{3} \mathrm{Si}\right)_{3} \mathrm{SiOH}$. The NMR data for $\mathbf{2}_{2}$ recorded in benzene- $d_{6}$ are unremarkable, other than the fact that each bridging siloxide gives rise to its own set of resonances in ${ }^{1} \mathrm{H},{ }^{13} \mathrm{C}\left\{{ }^{1} \mathrm{H}\right\}$ and ${ }^{29} \mathrm{Si}$ NMR spectroscopy (see $\mathrm{SI})$. The complex crystallised as a dimer bridged by siloxo ligands (Figure 3, $C_{1}$-symmetry). Each of the non-equivalent barium atoms is three-coordinate, in a geometry between trigonal pyramidal and trigonal planar. The $\mathrm{Ba} 1-\mathrm{O}_{\text {siloxide }}$ and $\mathrm{Ba} 2-\mathrm{O}_{\text {siloxide }}$ interatomic distances, in the range 2.549(5)-2.612(5) $\AA$, average those found in $\mathbf{1}_{2}$. There is no indication for the presence of $\mathrm{Ba} \cdots \mathrm{H}-\mathrm{C}$ agostic contacts in the solid-state structure of 22 . The Ba1-N1 and Ba2-N2 distances (2.600(7) and 2.607(6) A) are slightly longer than in $\left[\mathrm{Ba}\left\{\mathrm{N}\left(\mathrm{SiMe}_{3}\right)_{2}\right\}_{2}\right]_{2}(2.576(3) \AA),{ }^{[34]}$ the only other three-coordinate barium complex with a terminal $\mathrm{N}\left(\mathrm{SiMe}_{3}\right)_{2}{ }^{-}$ amide in the CCDC database. This presumably reflects the steric constraint imposed by the bulky siloxide $\left(\mathrm{Me}_{3} \mathrm{Si}_{3} \mathrm{SiO}^{-}\right.$.

The DFT-optimised ${ }^{[35]}$ geometries for $\mathbf{1}_{2}$.thf, $\mathbf{1}_{2}$ and $\mathbf{2}_{\mathbf{2}}$ are fully consistent with their X-ray structures (Tables S35 and S36). Interestingly, that of $\mathbf{1}_{2}$ displays weaker $\mathrm{Ba} 1 \cdots \mathrm{H}$ interactions than suggested by XRD analysis, with only one Ba1 $\cdots \mathrm{H}$ contact $(2.90$ $\AA$ ) lower than $3.1 \AA$, suggesting moderate unsaturation for Ba1. This is supported by the near-identical natural atomic orbital (NAO) charges of Ba1 and Ba2 (resp. +1.88 and +1.87 ) and by the non-negligible HOMO-LUMO gap of $4.28 \mathrm{eV}$ (12.thf: $4.49 \mathrm{eV}$; 2. $5.21 \mathrm{eV}$ ). The LUMO of $\mathbf{1}_{\mathbf{2}}$ can be viewed as an $\mathrm{sp}^{3}$ hybrid on Ba1 (Figure S33). This accepting orbital is involved in the bonding with thf in 12.thf (bonding energy $=19.1 \mathrm{kcal} \cdot \mathrm{mol}^{-1}$ ). The electrostatic potential of $\mathbf{1}_{\mathbf{2}}$ (Figure S34) indicates also strong electrophilicity at $\mathrm{Ba} 1$. Surprisingly, the hypothetical symmetrical isomer of $\mathbf{1}_{2},\left[\mathrm{Ba}\left\{\mu_{2}-\mathrm{OSi}\left(\mathrm{SiMe}_{3}\right)_{3}\right\}\left\{\mathrm{OSi}\left(\mathrm{SiMe}_{3}\right)_{3}\right\}\right]_{2}\left(\mathbf{1}_{2}{ }^{\prime}\right.$, Figure S35), is $13.7 \mathrm{kcal} \cdot \mathrm{mol}^{-1}$ less stable than $\mathbf{1}_{2}$. 


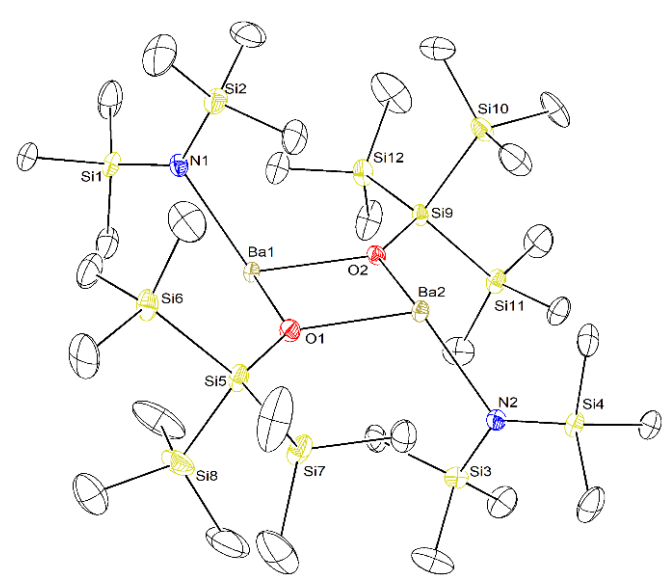

Figure 3. ORTEP representation of the molecular solid-state structure of $\left[\mathrm{Ba}\left\{\mu_{2}-\right.\right.$ $\left.\left.\mathrm{OSi}\left(\mathrm{SiMe}_{3}\right)_{3}\right\}\left\{\mathrm{N}\left(\mathrm{SiMe}_{3}\right)_{2}\right\}\right]_{2} \quad\left(\mathbf{2}_{2}\right)$. Only the main component of the disordered $\mathrm{SiMe}_{3}$ group (Si7) is depicted. $\mathrm{H}$ atoms omitted for clarity. Ellipsoids at the $50 \%$ probability level. Representative interatomic distances $(\AA)$ and angles $\left({ }^{\circ}\right)$ : Ba1$\mathrm{O} 2=2.557(5)$, Ba1-N1 = 2.600(7), Ba1-O1 = 2.610(5), Ba2-O1 = 2.549(5), Ba2$\mathrm{N} 2=2.607(6), \mathrm{Ba} 2-\mathrm{O} 2=2.612(5) ; \mathrm{O} 2-\mathrm{Ba} 1-\mathrm{N} 1=116.76(19), \mathrm{O} 2-\mathrm{Ba} 1-\mathrm{O} 1=$ $80.42(15), \mathrm{N} 1-\mathrm{Ba} 1-\mathrm{O} 1=114.93(19), \mathrm{O} 1-\mathrm{Ba} 2-\mathrm{N} 2=117.18(19), \mathrm{O} 1-\mathrm{Ba} 2-\mathrm{O} 2=$ $80.52(16), \mathrm{N} 2-\mathrm{Ba} 2-\mathrm{O} 2=114.85(18)$.

The $\mathrm{OSi}\left(\mathrm{SiMe}_{3}\right)_{3}$ ligand indeed prefers to bind in bridging rather than in terminal fashion, despite the constrained pyramidal coordination at $\mathrm{Ba} 1$ in $\mathbf{1}_{\mathbf{2}}$. The bonding energy of this ligand to the rest of the molecule is $38.3 \mathrm{kcal} \cdot \mathrm{mol}^{-1}$ stronger in $\mathbf{1} 2$ than in $\mathbf{1 2}_{2}$. Only part of this energy gain is lost in the unfavourable pyramidalisation of $\mathrm{Ba} 1$, so that $\mathbf{1}_{2}$ is the most stable isomer.

Complexes $\mathbf{1}_{\mathbf{2}}, \mathbf{2}_{\mathbf{2}}$ and the parent $\left[\mathrm{Ba}\left\{\mathrm{N}\left(\mathrm{SiMe}_{3}\right)_{2}\right\}_{2}\right]_{2}$ were used to catalyse the dehydrocoupling of hydrosilanes $\mathrm{R}_{3} \mathrm{SiH}$ with silanols $\mathrm{R}_{3}{ }_{3} \mathrm{SiOH}$ and deliver asymmetric siloxanes $\mathrm{R}_{3} \mathrm{Si}-\mathrm{O}-\mathrm{SiR}_{3}$ (Scheme 2). ${ }^{[36]}$ All reactions were run in benzene- $d_{6}$ at $30{ }^{\circ} \mathrm{C}$ unless otherwise specified. The products were all characterised by NMR and HRMS (see SI). In a benchmark reaction, all (pre)catalysts mediated with similar efficacy and full selectivity the formation of $\mathrm{Ph}_{2} \mathrm{HSiOSi}\left(\mathrm{SiMe}_{3}\right)$, starting from $\mathrm{Ph}_{2} \mathrm{SiH}_{2}$ and $\left(\mathrm{Me}_{3} \mathrm{Si}\right)_{3} \mathrm{SiOH}(1: 1)$. All subsequent reactions were carried out with the most synthetically convenient precatalyst, $\left[\mathrm{Ba}\left\{\mathrm{N}\left(\mathrm{SiMe}_{3}\right)_{2}\right\}_{2}\right]_{2}$. The coupling of $\left(p-\mathrm{X}-\mathrm{C}_{6} \mathrm{H}_{4}\right) \mathrm{SiH}_{3}(\mathrm{X}=\mathrm{MeO}, \mathrm{Me}$, $\mathrm{H}, \mathrm{F}$ ) with $\left(\mathrm{Me}_{3} \mathrm{Si}\right)_{3} \mathrm{SiOH}$ is quantitative and chemoselective in $4 \mathrm{~h}$ $\left([\mathrm{SiOH}]_{0} /[\mathrm{SiH}]_{0} /[\mathrm{Ba}]_{0}=50: 50: 1\right.$ with $\left.[\mathrm{Ba}]_{0}=1.8 \mathrm{mM}\right)$, affording solely the monocoupled products $\left(p-\mathrm{X}_{-}-\mathrm{C}_{6} \mathrm{H}_{4}\right) \mathrm{H}_{2} \mathrm{SiOSi}\left(\mathrm{SiMe}_{3}\right)_{3}$. Traces of $\left(p-\mathrm{X}_{-} \mathrm{C}_{6} \mathrm{H}_{4}\right) \mathrm{H}_{3-n} \mathrm{Si}\left\{\mathrm{OSi}\left(\mathrm{SiMe}_{3}\right)_{3}\right\}_{n}(\mathrm{n}=2$ or 3$)$, i.e. the diand tricoupled species arising from putative consecutive reactions could not be detected by NMR. Besides, with $\mathrm{PhSiH}_{3}$, the monocoupled $\mathrm{PhH}_{2} \mathrm{SiOSi}\left(\mathrm{SiMe}_{3}\right)_{3}$ was still the only product when the reactions were performed with a $2: 1$ or $3: 1$ excess of silanol vs. hydrosilane, after $12-24 \mathrm{~h}$ at $30-60{ }^{\circ} \mathrm{C}$. The coupling of $\mathrm{PhSiH}_{3}$ with ${ }^{t} \mathrm{Bu}_{3} \mathrm{SiOH} \quad\left([\mathrm{SiOH}]_{0} /[\mathrm{SiH}]_{0} /[\mathrm{Ba}]_{0}=50: 50: 1\right)$ returned quantitatively the monocoupled $\mathrm{PhSiH}_{2} \mathrm{OSi}^{\mathrm{B}} \mathrm{Bu}$ after $4 \mathrm{~h}$.

$$
\begin{aligned}
& \mathrm{RSiH}_{3}+\mathrm{R}_{3}^{\prime} \mathrm{SiOH} \stackrel{\text { [Ba] cat. }}{\longrightarrow} \mathrm{RSiH}_{3-\mathrm{n}}\left(\mathrm{OSiR}_{3}^{\prime}\right)_{\mathrm{n}} \quad \begin{array}{ll}
\mathrm{n}=1 & \text { monocoupling } \\
\mathrm{n}=2 & \text { dicoupling }
\end{array} \\
& \begin{array}{lll}
\text { benzene- } d_{6} & n=2 & \text { dicoupling } \\
& n=3 & \text { tricoupling }
\end{array} \\
& -\mathrm{H}_{2}
\end{aligned}
$$

Scheme 2. Ba-mediated dehydrocoupling of hydrosilanes and silanols.
On the other hand, the reaction with $\mathrm{Ph}_{3} \mathrm{SiOH}$ was more sluggish and less selective: hydrosilane conversion only reached $67 \%$ after $24 \mathrm{~h}$ yielding an equimolar mixture of $\mathrm{PhH}_{2} \mathrm{SiOSiPh}_{3}$ and the dicoupled $\mathrm{PhHSi}\left(\mathrm{OSiPh}_{3}\right)_{2} \cdot{ }^{[3]}$

$\mathrm{Ph}_{2} \mathrm{SiH}_{2}$ is also a suitable substrate, affording within $4 \mathrm{~h}$ full and selective conversion to $\mathrm{Ph}_{2} \mathrm{HSiOSi}\left(\mathrm{SiMe}_{3}\right)_{3}$ upon coupling with $\left(\mathrm{Me}_{3} \mathrm{Si}\right)_{3} \mathrm{SiOH}\left([\mathrm{SiOH}]_{0} /[\mathrm{SiH}]_{0} /[\mathrm{Ba}]_{0}=50: 50: 1\right)$. ${ }^{n} \mathrm{BuSiH}_{3}$ reacted also near quantitatively, but more slowly than $\mathrm{Ph}_{2} \mathrm{SiH}_{2}$ (see also below). $\mathrm{Et}_{2} \mathrm{SiH}_{2}$ and $\mathrm{Et}_{3} \mathrm{SiH}$ did not react under the same conditions, indicating that alkylsilanes are less reactive than arylsilanes. Moreover, it proved impossible to engage $\mathrm{Ph}_{3} \mathrm{SiH}$ (or $\mathrm{Et}_{3} \mathrm{SiH}$ ) in effective couplings with $\left(\mathrm{Me}_{3} \mathrm{Si}\right)_{3} \mathrm{SiOH}$, either at 30 or $60{ }^{\circ} \mathrm{C}$. The reactivity of the hydrosilanes hence appears to decrease with increasing substitution: $\mathrm{ArSiH}_{3}>\mathrm{Ar}_{2} \mathrm{SiH}_{2}>{ }^{n} \mathrm{BuSiH}$ $>\mathrm{Ar}_{3} \mathrm{SiH}, \mathrm{Et}_{2} \mathrm{SiH}_{2}, \mathrm{Et}_{3} \mathrm{SiH}$. Finally, the generation of

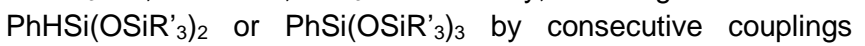
starting from $\mathrm{PhSiH}_{3}$ was not selective: with excess $\mathrm{R}_{3}{ }_{3} \mathrm{SiOH}$ vs $\mathrm{PhSiH}_{3}$, the main product remained $\mathrm{PhH}_{2} \mathrm{SiOSiR}_{3}{ }^{\text {[38] }}$

Preliminary kinetic investigations were carried out by NMR monitoring of reactions performed in benzene- $d_{6}$ (see $\mathrm{SI}$ ). The coupling of $\mathrm{Ph}_{2} \mathrm{SiH}_{2}$ and $\left(\mathrm{Me}_{3} \mathrm{Si}\right)_{3} \mathrm{SiOH}$ that produces $\mathrm{Ph}_{2} \mathrm{HSi}\left\{\mathrm{O}\left(\mathrm{SiMe}_{3}\right)_{3}\right\}$ catalysed by $\left[\mathrm{Ba}\left\{\mathrm{N}\left(\mathrm{SiMe}_{3}\right)_{2}\right\}_{2}\right]_{2}$ at $30{ }^{\circ} \mathrm{C}$ was chosen as a benchmark reaction, with $[\mathrm{Ba}]_{0}=1.8 \mathrm{mM}$ unless otherwise specified. As mentioned, $\mathrm{PhSiH}_{3}$ proved to be a substrate more reactive, less suited to kinetic monitoring, than $\mathrm{Ph}_{2} \mathrm{SiH}_{2}\left(k_{\mathrm{app}}=6.42(10) \cdot 10^{-4}\right.$ and $7.02(9) \cdot 10^{-5} \mathrm{~s}^{-1}$, respectively, at $\left.30{ }^{\circ} \mathrm{C} ;\left[\left(\mathrm{Me}_{3} \mathrm{Si}\right)_{3} \mathrm{SiOH}\right]_{0} /[\text { silane }]_{0} /[\mathrm{Ba}]_{0}=100: 100: 1\right)$.

The benchmark reaction revealed a partial first kinetic order in $\left[\mathrm{Ph}_{2} \mathrm{SiH}_{2}\right]$ and zeroth order in $\left[\left(\mathrm{Me}_{3} \mathrm{Si}\right)_{3} \mathrm{SiOH}\right]$. However, the catalyst is inhibited by $\left(\mathrm{Me}_{3} \mathrm{Si}\right)_{3} \mathrm{SiOH}$ : reaction rates decrease substantially upon increasing $\left[\left(\mathrm{Me}_{3} \mathrm{Si}\right)_{3} \mathrm{SiOH}\right]_{0}$ (Figure 4). For this reason, we failed to determine the partial kinetic order in $[\mathrm{Ba}]$. Although rare, substrate inhibition for $A e$ catalysts has been documented. ${ }^{[39]}$ Consistently with the observed inhibition process, we found that $\mathbf{1}_{\mathbf{2}}$, thought to be the active species in the catalytic manifold, easily binds $\left(\mathrm{Me}_{3} \mathrm{Si}\right)_{3} \mathrm{SiOH}$ to return $\mathbf{1}_{2}$. $\left(\mathrm{Me}_{3} \mathrm{Si}\right)_{3} \mathrm{SiOH}$. The identity of this adduct was confirmed by XRD analysis, but high disorder over $\mathrm{SiMe}_{3}$ sites prevented satisfactory refinement. Arrhenius analysis $\left(\left[\left(\mathrm{Me}_{3} \mathrm{Si}\right)_{3} \mathrm{SiOH}\right]_{0} /\left[\mathrm{Ph}_{2} \mathrm{SiH}_{2}\right]_{0} /[\mathrm{Ba}]_{0}=100: 100: 1\right.$, $20{ }^{\circ} \mathrm{C}<\mathrm{T}<60{ }^{\circ} \mathrm{C}$ ) provided $E_{\mathrm{a}}=15.0(6) \mathrm{kcal} \mathrm{mol}^{-1}$, a value consistent with the observed kinetically facile catalytic process. ${ }^{[40]}$

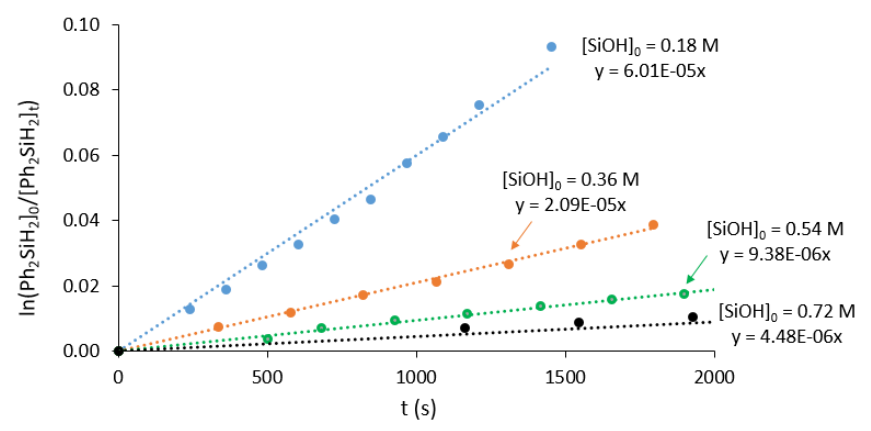

Figure 4. Semi-logarithmic plot of $\mathrm{Ph}_{2} \mathrm{SiH}_{2}$ conversion in the dehydrocoupling of $\mathrm{Ph}_{2} \mathrm{SiH}_{2}$ and $\left(\mathrm{Me}_{3} \mathrm{Si}\right)_{3} \mathrm{SiOH}$ catalysed by $\left[\mathrm{Ba}\left\{\mathrm{N}\left(\mathrm{SiMe}_{3}\right)_{2}\right\}_{2}\right]_{2}$, with up to a 3-fold excess of silanol vs hydrosilane $\left([\mathrm{SiOH}]_{0} /[\mathrm{SiH}]_{0} /[\mathrm{Ba}]_{0}=\mathrm{X}: 100: 1\right.$, benzene- $d_{6}$, $\left.30^{\circ} \mathrm{C},[\mathrm{Ba}]_{0}=1.8 \mathrm{mM}, \mathrm{X}=100-400\right)$. Decreasing reaction rates $\left(10^{6} \cdot k_{\mathrm{app}}=60.1\right.$, 20.9, 9.38 and $4.48 \mathrm{~s}^{-1}$ for $X=100,200,300$ and 400) with increasing $\left[\left(\mathrm{Me}_{3} \mathrm{Si}\right)_{3} \mathrm{SiOH}\right]_{0}$ indicate catalyst inhibition by the silanol. 
Under identical conditions $\left(\left[\left(\mathrm{Me}_{3} \mathrm{Si}\right)_{3} \mathrm{SiOH}\right]_{0} /\left[\mathrm{Ph}_{2} \mathrm{SiH}_{2}\right]_{0} /[\mathrm{Ba}]_{0}=\right.$ $\left.100: 100: 1,30{ }^{\circ} \mathrm{C}\right)$, the thf-adduct $\left.\left[\mathrm{Ba}\left\{\mathrm{N}\left(\mathrm{SiMe}_{3}\right)_{2}\right\}_{2} \text {.(thf }\right)_{2}\right]$ and $\left[\mathrm{Ba}\left\{\mathrm{N}\left(\mathrm{SiMe}_{3}\right)_{2}\right\}_{2}\right]_{2}$ displayed equal efficacy, $k_{\mathrm{app}}=6.08(2) \cdot 10^{-5}$ and $7.02(9) \cdot 10^{-5} \mathrm{~s}^{-1}$. The presence of coordinated thf in the precatalyst is therefore not detrimental to the reaction rate. ${ }^{[41]}$ The complexes $\left[\mathrm{Sr}\left\{\mathrm{N}\left(\mathrm{SiMe}_{3}\right)_{2}\right\}_{2}\right]$ and $\left[\mathrm{Ca}\left\{\mathrm{N}\left(\mathrm{SiMe}_{3}\right)_{2}\right\}_{2}\right]$ built around the smaller $\mathrm{Ae}$ elements were inactive under these conditions. With the more reactive substrate $\mathrm{PhSiH}_{3}$, they showed a lower activity (resp. $k_{\text {app }}$ $=2.10(4) \cdot 10^{-4}$ and $\left.2.31(4) \cdot 10^{-5} \mathrm{~s}^{-1}\right)$ than $\left[\mathrm{Ba}\left\{\mathrm{N}\left(\mathrm{SiMe}_{3}\right)_{2}\right\}_{2}\right]_{2}$ $\left(6.41(10) \cdot 10^{-4} \mathrm{~s}^{-1}\right)$, hence giving the trend $\mathrm{Ca}<<\mathrm{Sr}<\mathrm{Ba}$. The rates of couplings between $\left(p-\mathrm{X}-\mathrm{C}_{6} \mathrm{H}_{4}\right) \mathrm{SiH}_{3}(\mathrm{X}=\mathrm{MeO}, \mathrm{Me}, \mathrm{H}, \mathrm{F})$ and $\left(\mathrm{Me}_{3} \mathrm{Si}\right)_{3} \mathrm{SiOH}$ catalysed by $\left[\mathrm{Ba}\left\{\mathrm{N}\left(\mathrm{SiMe}_{3}\right)_{2}\right\}_{2}\right]_{2}$ augmented with electron-withdrawing groups, and decreased with electrondonating ones: $\mathrm{OMe}<\mathrm{Me}<\mathrm{H}<\mathrm{F} ;{ }^{n} \mathrm{BuSiH}_{3}$ was slower than the least reactive of these para-functionalised arylhydrosilanes. ${ }^{[42]}$ This reactivity trend suggests the presence of a negative charge localised on the $\mathrm{Si}_{\text {hydrosilane }}$ atom in the rate-limiting step and stabilised by electron-withdrawing substituents. The kinetic data gathered so far agree with a mechanism involving nucleophilic attack of the Ba-bound $\mathrm{O}_{\text {siloxide }}$ atom onto the incoming hydrosilane, thus generating a pentavalent hydrosilicate. Such scenario is akin to that established for the Ba-catalysed formation of silazanes ${ }^{[18]}$ and borasiloxanes, ${ }^{[6]}$ but further investigations are required to support this working hypothesis.

In summary, we have prepared unsupported Ba-siloxides, including the unusual $\left[\mathrm{Ba}_{2}\left\{\mu_{2}-\mathrm{OSi}\left(\mathrm{SiMe}_{3}\right)_{3}\right\}_{3}\left\{\mathrm{OSi}\left(\mathrm{SiMe}_{3}\right)_{3}\right\}\right]$. This complex and its amido parent $\left[\mathrm{Ba}\left\{\mathrm{N}\left(\mathrm{SiMe}_{3}\right)_{2}\right\}_{2}\right]_{2}$ catalyse the fast and chemoselective dehydrocoupling of silanols and hydrosilanes to create asymmetric siloxanes with minimal release of byproducts $\left(\mathrm{H}_{2}\right)$. This catalysis is most effective with $\mathrm{Ba}$, while $\mathrm{Sr}$ and even more so $\mathrm{Ca}$ are less efficient. We are now working on expanding the substrate scope for this process, and on delineating its operative mechanism. However, mechanistic investigations are hampered by catalyst inhibition by the silanol substrate.

Keywords: barium $\cdot$ siloxide $\cdot$ asymmetric siloxanes $•$ dehydrocoupling catalysis $\bullet$ low-coordinate complex

[1] D. C. Bradley, Chem. Rev. 1989, 89, 1317.

[2] S. Mishra, S. Daniele, Chem. Rev. 2015, 115, 8379.

[3] B. Liu, T. Roisnel, J.-P. Guégan, J.-F. Carpentier, Y. Sarazin, Chem. Eur. J. 2012, 18, 6289.

[4] T. Heidemann, S. Mathur, Inorg. Chem. 2017, 56, 234.

[5] G. B. Deacon, P. C. Junk, G. J. Moxey, M. Guino-o, K. Ruhlandt-Senge, Dalton Trans. 2009, 4878.

[6] E. Le Coz, V. Dorcet, T. Roisnel, S. Tobisch, J.-F. Carpentier, Y. Sarazin Angew. Chem. Int. Ed. 2018, 57, 11747.

[7] K. G. Caulton, M. H. Chisholm, S. R. Drake, W. E. Streib, Angew. Chem. Int. Ed. 1990, 29, 1483.

[8] W. A. Wojtczak, M. J. Hampden-Smith, E. N. Duesler, Inorg. Chem. 1996, 35,6638 .

[9] S. R. Drake, W. E. Streib, K. Folting, M. H. Chisholm, K. G. Caulton, Inorg. Chem. 1992, 31, 3205.

[10] J. A. Darr, S. R. Drake, D. J. Williams, A. M. Z. Slawin, J. Chem. Soc., Chem. Commun. 1993, 866.
[11] P. Shao, D. J. Berg, G. W. Bushnell, Can. J. Chem. 1995, 73, 797.

[12] B. Freitag, P. Stegner, K. Thum, C. A. Fischer, S. Harder, Eur. J. Inorg. Chem. 2018, 1938.

[13] A. Staubitz, A. P. M. Robertson, I. Manners, Chem. Rev. 2010, 110, 4079

[14] H. C. Johnson, T. N. Hooper, A. S. Weller, Top. Organometal. Chem. 2015, 49, 153.

[15] M. S. Hill, D. J. Liptrot, C. Weetman, Chem. Soc. Rev. 2016, 45, 972.

[16] T. E. Stennett, S. Harder, Chem. Soc. Rev. 2016, 45, 1112.

[17] M. S. Hill, D. J. Liptrot, D. J. MacDougall, M. F. Mahon, T. P. Robinson, Chem. Sci. 2013, 4, 4212.

[18] C. Bellini, J.-F. Carpentier, S. Tobisch, Y. Sarazin, Angew. Chem. Int. Ed. 2015, 54, 7679.

[19] C. Bellini, C. Orione, J.-F. Carpentier, Y. Sarazin, Angew. Chem. Int. Ed. 2016, 55, 3744.

[20] C. Bellini, T. Roisnel, J.-F. Carpentier, S. Tobisch, Y. Sarazin, Chem. Eur. J. 2016, 22, 15733.

[21] J. C. McDonald, G. M. Whitesides, Acc. Chem. Res. 2002, 35, 491

[22] K. Matsumoto, S. Shimada, K. Sato, Chem. Eur. J. 2019, 25, 920.

[23] K. Kuroda, A. Shimojima, K. Kawahara, R. Wakabayashi, Y. Tamura, Y. Asakura, M. Kitahara, Chem. Mater. 2014, 26, 211.

[24] Z. M. Michalska, Transition Met. Chem. 1980, 5, 125.

[25] Y. Satoh, M. Igarashi, K. Sato, S. Shimada, ACS Catal. 2017, 7, 1836.

[26] J. Kaźmierczak, K. Kuciński, D. Lewandowski, G. Hreczycho, Inorg. Chem. 2019, 58, 1201.

[27] J. Chojnowski, S. Rubinsztajn, J. A. Cella, W. Fortuniak, M. Cypryk, J. Kurjata, K. Kaźmierski, Organometallics 2005, 24, 6077.

[28] J. Chojnowski, W. Fortuniak, J. Kurjata, S. Rubinsztajn, J. A. Cella, Macromolecules 2006, 39, 3802.

[29] K. Matsumoto, K. V. Sajna, Y. Satoh, K. Sato, S. Shimada, Angew. Chem nt. Ed. 2017, 56, 3168.

[30] K. Matsumoto, Y. Oba, Y. Nakajima, S. Shimada, K. Sato, Angew. Chem Int. Ed. 2018, 57, 4637.

[31] T. J. Boyle, J. M. Sears, D. Perales, R. E. Cramer, P. Lu, R. O. Chan, B A. Hernandez-Sanchez, Inorg. Chem. 2018, 57, 8806.

[32] L. Yang, D. R. Powell, R. P. Houser, Dalton Trans. 2007, 955.

[33] O. Michel, S. König, K. W. Törnroos, C. Maichle-Mössmer, R. Anwander, Chem. Eur. J. 2011, 17, 11857.

[34] B. A. Vaartstra, J. C. Huffman, W. E. Streib, K. G. Caulton, Inorg. Chem 1991, 30, 121.

[35] PBE0/Def2-TZVP-D3 level. See computational details in the SI.

[36] Couplings do not occur without barium (pre)catalyst.

[37] With $\mathrm{Ph}_{3} \mathrm{SiOH}$, dehydrocouplings are plagued by the formation of $\mathrm{Ph}_{3} \mathrm{SiOSiPh}_{3}$ generated upon Ba-promoted dehydration of the silanol.

[38] For instance, the reaction with $\left[\left(\mathrm{Me}_{3} \mathrm{Si}\right)_{3} \mathrm{SiOH}\right]_{0} /\left[\mathrm{PhSiH}_{3}\right]_{0} /[\mathrm{Ba}]_{0}=40: 20: 1$ for $24 \mathrm{~h}$ at $25^{\circ} \mathrm{C}$ only returned a $2: 1$ mixture of $\mathrm{PhSiH}_{2} \mathrm{OSi}\left(\mathrm{SiMe}_{3}\right)_{3}$ and $\mathrm{PhSiHO}\left\{\mathrm{Si}\left(\mathrm{SiMe}_{3}\right)_{3}\right\}_{2}$ after near-quantitative conversion of $\mathrm{PhSiH}_{3}$.

[39] M. R. Crimmin, M. Arrowsmith, A. G. M. Barrett, I. J. Casely, M. S. Hill, P. A. Procopiou, J. Am. Chem. Soc. 2009, 131, 9670.

[40] Full Eyring analysis could not be performed, as we could not assess the intrinsic rate constant $k$ owing to the uncertainty on the partial kinetic order in [Ba]. $\Delta \mathrm{H}^{\ddagger}=14.4(6) \mathrm{kcal} \cdot \mathrm{mol}^{-1}$, was determined unambiguously. Uncertainty concerned $\Delta \mathrm{S}^{\ddagger}$; values of $-16.8(5)$ and $-4.3(5) \mathrm{cal} \cdot \mathrm{mol}^{-1} \cdot \mathrm{K}^{-1}$ were estimated assuming partial kinetic orders of 1 or 2 in [Ba]. These values are consistent with an associative mechanism, as might be expected for such Ae-mediated dehydrocouplings, see refs [17-20].

[41] As seen in the preliminary experiments, complexes $\mathbf{1}_{\mathbf{2}}$ and $\mathbf{2}_{\mathbf{2}}\left(k_{\mathrm{app}}=\right.$ $6.44(7) \cdot 10^{-5}$ and $5.72(7) \cdot 10^{-5} \mathrm{~s}^{-1}$ ) displayed reaction rates identical to those of these two Ba-amide precatalysts.

[42] $\left[\left(\mathrm{Me}_{3} \mathrm{Si}\right)_{3} \mathrm{SiOH}\right]_{0} /\left[\left(p-\mathrm{X}-\mathrm{C}_{6} \mathrm{H}_{4}\right) \mathrm{SiH}_{3}\right]_{0} /[\mathrm{Ba}]_{0}=100: 100: 1,30{ }^{\circ} \mathrm{C},[\mathrm{Ba}]_{0}=1.8$ $\mathrm{mM}$. For $\mathrm{X}=\mathrm{OMe} / \mathrm{Me} / \mathrm{H} / \mathrm{F}, 10^{5} \cdot \mathrm{k}_{\mathrm{app}}=8.83(2) / 26.3(1) / 64.1(1) / 133.8(1) \mathrm{s}^{-}$ ${ }^{1}$. For ${ }^{n} \mathrm{BuSiH}_{3}, k_{\text {app }}=2.94(5) \cdot 10^{-5} \mathrm{~s}^{-1}$. 
WILEY-VCH

\section{Entry for the Table of Contents}

\section{COMMUNICATION}

The first unsupported barium siloxides have been structurally authenticated. They act as effective molecular catalysts for the dehydrocoupling of hydrosilanes with silanols to generate asymmetric siloxanes $\mathrm{R}_{3} \mathrm{Si}-\mathrm{O}-\mathrm{SiR}_{3}$.
ASYMMETRIC SILOXANES via dehydrocoupling

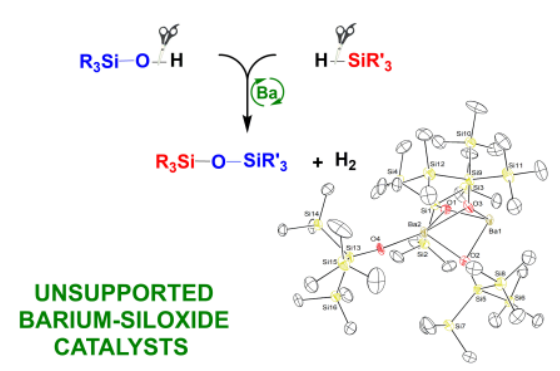

Erwann Le Coz, Samia Kahlal, JeanYves Saillard, * Thierry Roisnel, Vincent Dorcet, Jean-François Carpentier and Yann Sarazin*

Page No. - Page No.

Barium siloxides and catalysed formation of Si-O-Si' motifs 